\title{
Impact of three genetic musculoskeletal diseases: a comparative synthesis of achondroplasia, Duchenne muscular dystrophy and osteogenesis imperfecta
}

Maman Joyce Dogba ${ }^{1,2^{*}}$, Frank Rauch ${ }^{1}$, Erin Douglas ${ }^{1}$ and Christophe Bedos ${ }^{3,4}$

\begin{abstract}
Achondroplasia, Duchenne muscular dystrophy, and osteogenesis imperfecta are among the most frequent rare genetic disorders affecting the musculoskeletal system in children. Rare genetic disorders are severely disabling and can have substantial impacts on families, children, and on healthcare systems. This literature review aims to classify, summarize and compare these non-medical impacts of achondroplasia, Duchenne muscular dystrophy and osteogenesis imperfecta.
\end{abstract}

Keywords: Rare genetic diseases, Societal and family impact, Burden of care, Achondroplasia, Duchenne muscular dystrophy, Osteogenesis imperfecta, Quality of life, Scoping review

\section{French abstract}

L'achondroplasie, la dystrophie musculaire de Duchenne et l'ostéogenèse imparfaite sont des maladies génétiques rares du système musculo-squelettique pédiatrique. On assiste à un intérêt croissant pour l'étude des maladies génétiques rares dont la plupart sont handicapantes et ont des conséquences néfastes sur familles, les patients et les systèmes de santé. Malgré leurs spécificités, certaines conséquences des maladies génétiques rares sont communes et gagneraient à être étudiées de façon générique. Cependant, plusieurs travaux continuent d'adopter une approche spécifique à une maladie. Par ailleurs, on assiste à un foisonnement de termes qui évaluent les conséquences des maladies génétiques rares (qualité de vie, impact, effet, fardeau etc....). Si ce pléthore de termes reflète la complexité du sujet, il rend difficile la synthèse et la comparaison entre maladies. Dans cet article, les auteurs classifient puis effectuent une revue narrative et comparative des impacts de trois maladies génétiques musculo-squelettiques pédiatriques: l'achondroplasie, la dystrophie musculaire de Duchenne et l'ostéogenèse imparfaite.

\section{Introduction}

A rare disease is defined as one that affects less than one in 2000 individuals in Europe and one in 1250 in the United States [1]. Most rare diseases are severely disabling genetic disorders that can have substantial impacts on families and children, and on healthcare systems $[2,3]$.

\footnotetext{
* Correspondence: joyce-maman.dogba@fmed.ulaval.ca

'Shriners Hospital for Children, 1529 Cedar Avenue, H3G 1 A6 Montreal,

QC, Canada

2Department of family and emergency medicine, Faculty of Medicine,

Université Laval, 1050 Medicine Avenue, Quebec G1V0A6, Canada

Full list of author information is available at the end of the article
}

Despite their specific biomedical features, many rare genetic diseases (RGDs) share several non-medical characteristics, in particular, their psychosocial consequences [4]. While it is acknowledged that research on these non-medical common features may benefit from a non-categorical approach, a disease-specific approach remains common. In addition, the literature assessing these issues is sometimes difficult to summarize due to the inconsistent use of terminology. Several terms are commonly used in the literature to examine the impacts of RGDs: burden of care, quality of life, impacts, consequences, meaning of leaving, and coping strategies [5-7]. This proliferation of concepts, 
which depends on research interest and disciplinary tradition (e.g., biomedical, psychological, economic, social and nursing) reflects the complexity of the field, but may also lead to a fragmented version of 'the same reality'. A clear and synthetized conceptualization of the impacts of RGDs with a non-disease-specific approach is warranted. Scoping reviews, an increasingly popular knowledge synthesis approach in health care, can help in such conceptualization [8]. Moreover, scoping reviews can yield a framework for collating and summarizing results that can empower patients and families, raise awareness among health care professionals, identify knowledge gaps and priorities for future research, and advocate for policies to develop support services for families [8,9].

This paper reports a scoping review that describes the literature on non-medical impacts for patients and families. Due to the exploratory nature of the review and to reflect the research areas of our team, we delineated the focus of this review to three common RGDs in the pediatric orthopedic context: achondroplasia, Duchenne muscular dystrophy (DMD) and osteogenesis imperfecta (OI). These three RGDs are single-gene musculoskeletal diseases characterized by physical disability and little or no impairment of mental ability. Table 1 provides their clinical and genetic characteristics.

The three specific objectives of this review research were: i) to categorize the types of non-medical impacts of achondroplasia, DMD and OI; ii) to summarize these impacts; and iii) to discuss findings on these impacts across the three diseases.

\section{Methods}

While systematic reviews synthesize the complete nature of a particular field, outlining what approaches are effective and where further research is required, scoping reviews are exploratory projects that map the literature available on a topic, identifying the key concepts, theories, sources of evidence, and gaps in the research [10]. We therefore opted for a scoping review to allow for a quick mapping of the "key concepts underpinning a research area and the main sources and types of evidence available" [11]. We adopted a broad definition of impact that includes consequences of, but also reactions to, a disease. We followed the five stages suggested for a quality scoping review: i) identification of the research question; ii) identification of relevant studies; iii) selection of studies to include in the review; iv) charting of information and data within the included studies; and v) collating, summarizing and reporting results of the review [11].

\section{Identification of relevant publications}

From March to June, 2013, we conducted a search of the literature in three electronic databases: Web of Science, CINAHL, and MEDLINE. The following two string combinations of keywords were used: [Impact, burden, quality of life, living with, coping, adjustment, well-being, quality of life, effects, impacts, responses, reactions, psychosocial] AND [Rare genetic disease/disorder, rare childhood disease, osteogenesis imperfecta, brittle bone disease, Duchenne muscular dystrophy, achondroplasia, chronic illness, musculoskeletal system, physical disorders]. We complemented our search for publications with a systematic screening of the table of contents of specific journals dedicated to rare diseases (e.g. Orphanet Journal of Rare Diseases) and a screening of references of relevant publications. Opinions, commentaries, letters, editorials, and publications without an abstract were immediately initially excluded. The initial search yielded the identification of

Table 1 Key features of achondroplasia, DMD and OI

\begin{tabular}{|c|c|c|c|}
\hline Disease, features & Achondroplasia & Duchenne muscular dystrophy & Osteogenesis imperfecta \\
\hline $\begin{array}{l}\text { Orphanet number and } \\
\text { synonyms }\end{array}$ & ORPHA 15 & ORPHA 98896 & ORPHA 666 \\
\hline Prevalence & $4 / 100,000$ & 30/100,000 males & $10 / 100,000$ \\
\hline Genetic defect & $\begin{array}{l}\text { Change in the DNA for fibroblast } \\
\text { growth factor receptor } 3 \text { (FGFR3), } \\
\text { which causes an abnormality } \\
\text { of cartilage formation }\end{array}$ & $\begin{array}{l}\text { Absence of the protein dystrophin in } \\
\text { skeletal muscle, myocardium, and brain }\end{array}$ & $\begin{array}{l}\text { Mutation in gene encoding collagen type l; } \\
\text { deficiencies in proteins that interact with collagen } \\
\text { (CRTAP, P3H1, PPIB, Serpin H1 and FKBP10) }\end{array}$ \\
\hline Mode of transmission & Autosomal dominant & X-linked recessive & $\begin{array}{l}\text { Primarily autosomal dominant, although } \\
\text { recessive cases reported }\end{array}$ \\
\hline Clinical symptoms & Short stature & $\begin{array}{l}\text { Progressive weakness, contractures, spinal } \\
\text { deformity, restrictive lung functional pattern, } \\
\text { and cardiomyopathy }\end{array}$ & Increased bone fragility; fractures \\
\hline Cognitive impairment & None noted & $\begin{array}{l}\text { Some variable degree of cognitive } \\
\text { involvement }\end{array}$ & None noted \\
\hline Diagnosis & Neonatal; Prenatal in USA & Childhood & Variable \\
\hline Lifespan & Unimpaired & Death in early adulthood & $\begin{array}{l}\text { Variable (unimpaired in types I, and IV), possibly } \\
\text { somewhat decreased in type III) [81] }\end{array}$ \\
\hline
\end{tabular}


845 publications. After removing 8 duplicates, two authors independently selected publications addressing the nonmedical impacts of Achondroplasia, DMD and OI, based on the titles and the abstracts. Publications that addressed a rare genetic disease other than the three retained by the research group were excluded from this review, as were publications focussed on the identification of genes. In the case of disagreement among authors, the full-text publications were reviewed by a third senior author. A total of 65 full-text publications remained at this stage of the review.

\section{Selection of studies to include in the review}

For inclusion in our study, publications had to be i) published between 1980 and 2013; ii) in English or French; iii) about non-medical effects and responses to OI, achondroplasia and DMD; and iv) have a well-defined methodology. Because a scoping review is not intended to assess the quality of studies, emphasis was not placed on methodological rigor of the retained studies. At this second stage, 8 publications were excluded as they examined medical impacts of a treatment or intervention, and 57 publications were retained. Figure 1 displays the study selection flow diagram. We used a data extraction grid to gather the following items: i) general information (e.g., type of study, country, focus); and ii) the relevance of the article to our study and the scientific information such as concepts, theoretical orientation, methodology, and research tradition.

\section{Collating, summarizing and reporting results of the review}

The 57 retained publications were coded using qualitative structure coding [12] with Nvivo 10 (QSR International) and Endnote X6. From this, we identified main study themes and grouped based on similarity. We iteratively constructed a working framework (Figure 2) to examine separately the extent, range and research activity for OI, achondroplasia and DMD. The adequacy of the framework to review question was tested independently by two authors (MJD and ED) on 10 selected articles. Disagreements were solved by discussion among these authors or by the adjudication of a senior author (FR).

To ensure consistent mapping and analysis of data, we developed a glossary of codes used to classify the impacts as follows: i) 'scope' refers to whether the article addresses one or several pediatric rare musculoskeletal

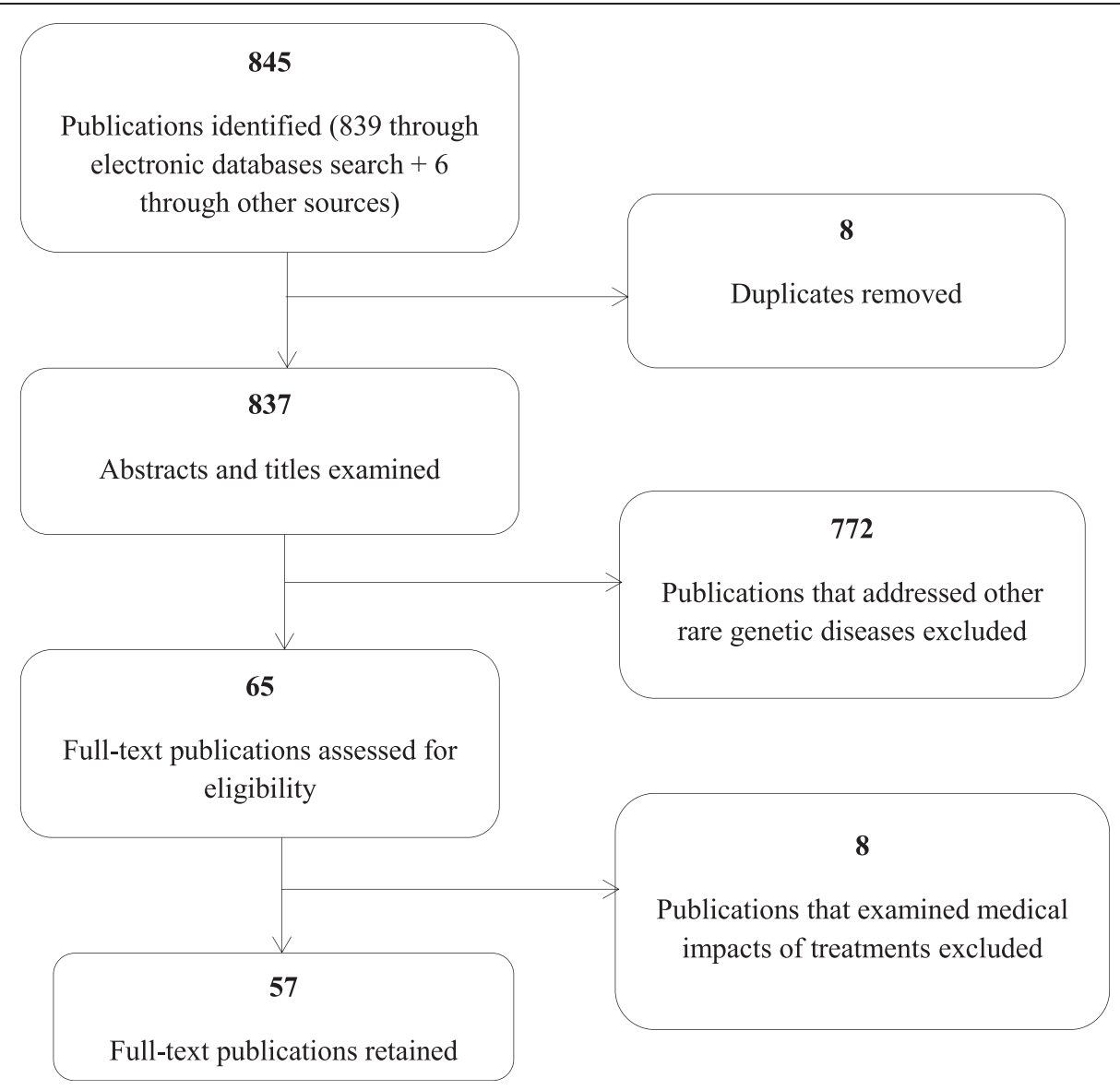

Figure 1 Study selection flow diagram. 


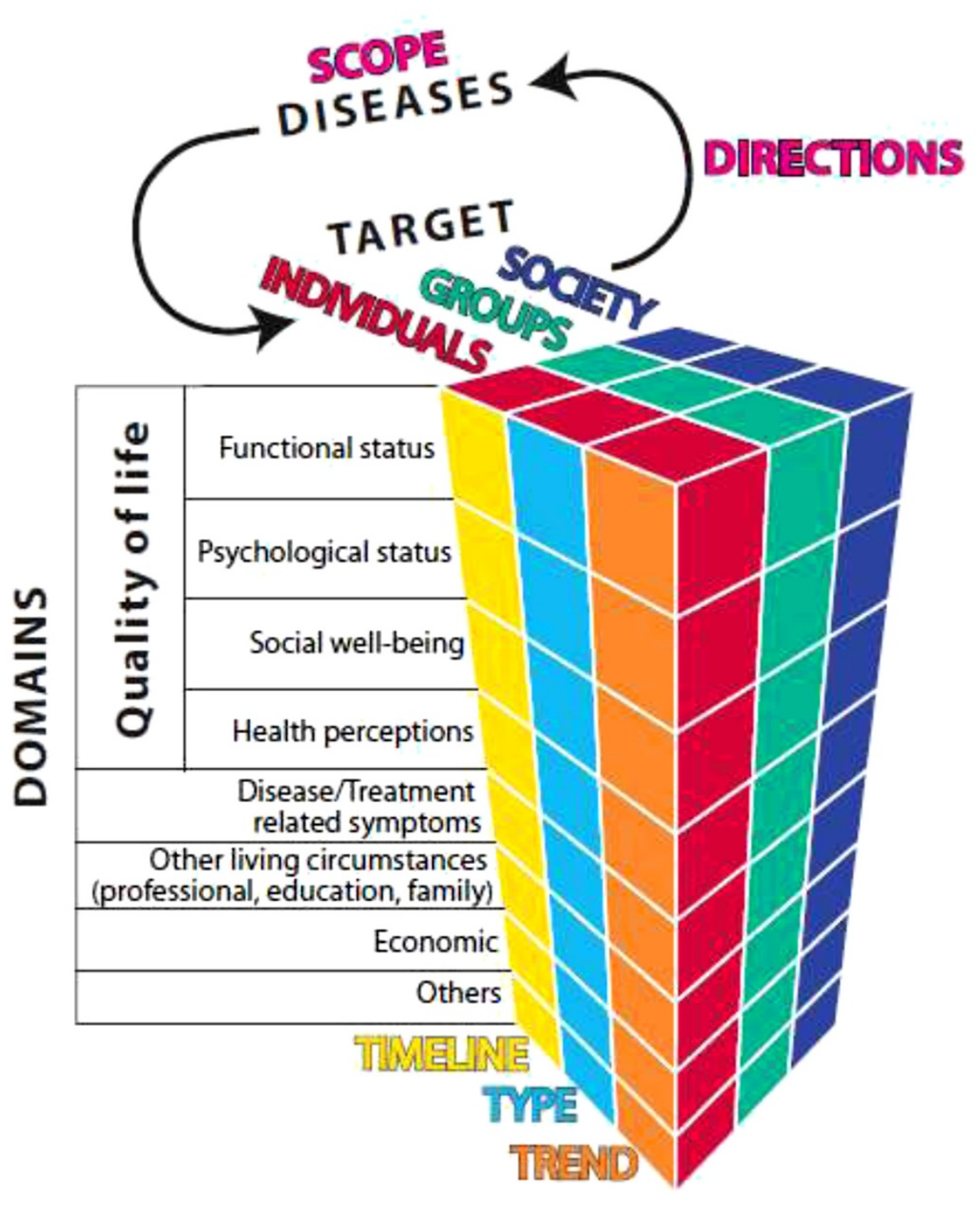

Figure 2 Framework redefining impacts of rare genetic diseases.

disorders; ii) 'direction' was used to capture whether the article studied the 'Effect of Disease' (Direction 1) or 'Response to the Disease' (Direction 2); iii) 'target' refers to three distinct groups of focus: 'individuals' such as patients, adults, carers, or siblings; 'groups' such as physicians, caregivers, or school teachers; and 'societies' such as communities or society as a whole; iv) 'timeline' and 'trend' refer to the temporal analysis of impacts; and v) 'type' refers to positive or negative consequences; finally vi) 'domain' refers to the aspect of QOL being studied (psychological, functional and so on) or the research tradition or academic discipline used to study the impacts. Once the 57 publications were categorized, we performed a narrative review of the findings on the impacts separately for each disease, and then critically compared the findings across the three diseases. An overview of the distribution of the publications using the components of our working framework is presented, as well as a summary of the major findings of the publications achondroplasia, DMD and OI. Finally, we discuss how research compares across the three diseases.

\section{Results}

A total of 57 publications on non-medical impacts are included in this review study: 3 about achondroplasia [13-15], 39 about DMD [16-54] and 15 about OI [55-69].

\section{Overview of the publications}

The majority of the publications (50) were original research focused on a single disease, while 6 publications concerned two diseases (DMD and other diseases), and 1 publication was a literature review.

The target group assessed was spread between the experiences of the individual with the disease (26), the 
impact of the disease on families (18), the experience of caregivers only (8), or were focused on the impacts of other groups or tool development and reviews of the literature (5; physicians' attitudes, the effects on community).

The direction of the impacts was explicitly stated in 44 of the 57: 31 addressed the effects and impacts of living with achondroplasia, DMD or OI, 13 addressed responses to living with the disease on individuals, groups or society (such as resilience, adjustment, coping strategies and attitudes). In these 44 papers, the occurrence of a RGD was conceptualised as a source of stress to which people react. The direction was either a combination of directions, or not explicitly stated, in the remaining 13 papers. Table 2 outlines the studies according to the scope, target, direction, timeline, trend, and type of impacts.

Papers were also spread over several domains (as defined above), with 15 examining the quality of life (QOL) through a normative and validated measure of function, psychosocial well-being, and perception of health (2 achondroplasia, 7 DMD, and 6 OI). Psychosocial impacts on their own were addressed in 18 publications (14 DMD, 4 OI), and functional status on its own was addressed in 10 publications (1 achondroplasia, 6 DMD, 3 OI). The remaining 14 publications assessed the domains of illness experience, utilisation of healthcare services, palliative care, medical staff reactions to the disease, or newborn screening. Tables 3, 4 and 5 report the general information and major findings of the publications for the domain.

\section{Narrative review}

\section{The non-medical impacts of achondroplasia}

Evidence from the publications on achondroplasia suggests that affected individuals have an impaired QOL when compared to first-degree relatives [14]. The lower QOL could mainly be linked to psychosocial limitations including lower self-esteem and social stigmatization, to the extent that serial lower limb lengthening appeared a good option to patients despite its numerous complications $[13,15]$. The functional status of patients with achondroplasia was impaired by back pain and pain in the lower extremity, resulting in some cases in complete cessation of work. However, the functional limitation and psychological distress remained unchanged over time [13].

\section{The non-medical impacts of DMD}

The overall QOL of parents and their children who are affected with DMD was reported to be lower than in the general population, particularly due to impairments in physical functioning $[19,42]$. Boys with DMD reported significantly lower QOL than healthy peers in physical and psychosocial domains. Physical limitations increased with age as respiratory problems and muscle weaknesses occurred. However, despite the progressive course of the disease, the psychosocial QOL tended to be higher in adolescents with DMD than in their younger counterparts, suggesting the development of effective coping strategies over time $[41,50,52]$. For parents, the psychosocial impacts were reported to be great, and quality of life decreased even more around the period of patient transition to wheelchair [22,23]. Finally, parental reports of QOL did not consistently match that of their children, with many underestimating their child's QOL [23].

The 14 studies that solely examined the psychological impacts of DMD reported higher levels of anxiety, depression, and guilt in parents, particularly in mothers $[25,26,46]$. However, early diagnosis and family hardiness (the energy resources of the family such as commitment, challenge, and control) were reported to positively influence parental psychological adjustments, the patients' level of resilience and the reactions of siblings $[20,24,26,29,34,43,48,49,51,53]$.

In addition to the psychological impacts, parents, particularly mothers, reported caring for their children with DMD to be burdensome (help for bathing, toileting), costly in terms of time, and contributing to increased social isolation [44]. Altogether, participation in daily activities and social life was reduced for patients. Siblings of adolescents with DMD seemed more negatively affected than siblings of healthier counterparts.

\section{The non-medical impacts of $\mathrm{OI}$}

There was little difference in the overall QOL of those diagnosed with OI as compared to the general population. Functional limitations were more important in patients with severe forms of OI, and higher life satisfaction, resilience, low depression and higher social achievements were common $[55,64,68]$. Parents reported several accusations of child abuse, lack of information on the disease, disruptions of family activities due to the occurrence of fractures, and social isolation [56-58].

\section{Other findings}

Besides these psychosocial impacts of achondroplasia, DMD and OI on families, the impacts on groups and the society were broached in few studies. Two publications examined the attitudes of medical staff about a condition or related treatments options $[17,40]$. These publications concluded that physicians could promote some experimental treatment options provided that there was a shareddecision making with families. The medical staffs were also found to support newborn and prenatal screening whenever available. Finally, it should be noted that the impacts on the use of health services and economic factors were not assessed in the papers included in this review.

\section{Discussion}

The impacts of achondroplasia, DMD and OI on families reported in this review are derived from in-depth 
Table 2 Overview of the publications according to diseases, scope, target and directions of the impacts

\begin{tabular}{|c|c|c|c|c|c|c|c|c|c|}
\hline \multirow[t]{2}{*}{ Disease } & \multicolumn{2}{|c|}{ Scope of the impacts } & \multicolumn{4}{|l|}{ Target of the impacts } & \multicolumn{3}{|c|}{ Directions of the impacts } \\
\hline & One disease & Multiple diseases & Patients only & Carers only & Families & $\begin{array}{l}\text { Other } \\
\text { groups/society }\end{array}$ & Effects of the disease & $\begin{array}{l}\text { Responses to } \\
\text { the disease }\end{array}$ & NA \\
\hline $\begin{array}{l}\text { Achondroplasia } \\
(\mathrm{N}=3)\end{array}$ & $3,[13-15]$ & 0 & $2,[13,15]$ & 0 & $1,[14]$ & 0 & $2,[13,15]$ & $1,[14]$ & 0 \\
\hline DMD, (N =39) & $\begin{array}{l}33,[16,18-20 \\
22-34,38,40-54]\end{array}$ & 6, $[17,21,35-37,39]$ & $\begin{array}{l}15,[20,21,23,29,33,34 \\
41,43,45,47,50,51,53,54]\end{array}$ & 7, [16,24,26,27,36,39,44] & $\begin{array}{l}12,[18,19,23,25,28 \\
31,32,35,46,48,49,52]\end{array}$ & $5,[17,37,38,40,42]$ & $\begin{array}{l}\text { 15, [19,20,22,23,27,31, } \\
33,39,41,43,44,50-53]\end{array}$ & $\begin{array}{l}\text { 11, [16,24-26, } \\
28-30,34,47-49]\end{array}$ & $\begin{array}{l}13,[17,18,21,32 \\
35-38,40,42,45,46]\end{array}$ \\
\hline $\mathrm{Ol},(\mathrm{N}=14)$ & $15,[55-69]$ & 0 & 9, [55,59,61-64,66,68,69] & $1,[65]$ & $5,[56-58,60,67]$ & 0 & 14, [55-63,65-69] & $1,[64]$ & 0 \\
\hline
\end{tabular}


Table 3 Summary of findings of publications on non-medical impacts of achondroplasia

\begin{tabular}{|c|c|c|c|c|c|}
\hline Publication & Major findings & Domain & Instruments used & Sample (N) & Country \\
\hline Gollust, Thompson et al. [14] & $\begin{array}{l}\text { This index measures mean total QOL } \\
\text { and indicates higher QOL. Respondents } \\
\text { judge their satisfaction with } 34 \text { distinct } \\
\text { life domains and judge how important } \\
\text { each is to their life, producing QOL } \\
\text { scores that reflect respondents' values. }\end{array}$ & $\mathrm{QOL}$ & $\begin{array}{l}\text { Survey, Ferrans and } \\
\text { Powers Quality of } \\
\text { Life Index }\end{array}$ & $\begin{array}{l}189 \text { affected individuals; } \\
136 \text { unaffected } 1 \mathrm{st} \\
\text { degree relatives }\end{array}$ & USA \\
\hline Kim, Balce et al. [15] & $\begin{array}{l}\text { The physical and functional scores of } \\
\text { patients who had surgery were equivalent } \\
\text { to those of the nonsurgical group. Even } \\
\text { with numerous complications, our data } \\
\text { show serial lower limb lengthening is a } \\
\text { good option for patients with } \\
\text { achondroplasia in terms of good QOL } \\
\text { scores. The patients who had surgery for } \\
\text { lengthening scored well in the mental } \\
\text { component of the SF-36 and in the } \\
\text { Rosenberg self-esteem questionnaire. }\end{array}$ & QOL & $\begin{array}{l}\text { American Academy of } \\
\text { Orthopaedic Surgeons } \\
\text { (AAOS) lower limb, SF-36, } \\
\text { Rosenberg self-esteem } \\
\text { scores }\end{array}$ & $\begin{array}{l}22 \text { patients who had } \\
\text { bilateral leg lengthening, } \\
22 \text { patients who did not }\end{array}$ & Korea \\
\hline Ain, Abdullah et al. [13] & $\begin{array}{l}\text { Back pain associated with proximal and/or } \\
\text { distal leg pain was associated with higher } \\
\text { functional disability, more psychological } \\
\text { distress, and more physical symptoms. } \\
\text { Increase in healthcare use and increase } \\
\text { in the number of individuals who had } \\
\text { stopped working or changed their type } \\
\text { of work because of back or leg pain } \\
\text { on follow-up. }\end{array}$ & $\begin{array}{l}\text { Functional } \\
\text { limitations and } \\
\text { psychological } \\
\text { impacts }\end{array}$ & $\begin{array}{l}\text { Symptoms Check List } \\
\text { (SCL90R), } 10 \text { Beck } \\
\text { Depression Inventory } \\
\text { (BDI), State-Trait Anxiety } \\
\text { Inventory (STAI) }\end{array}$ & 181 affected adults & USA \\
\hline
\end{tabular}

qualitative analysis of subjective illness experiences or objective normative measures of QOL. These methodological specificities resulted in variations in the impacts between and within similar categories of publications that may limit the comparison across the three diseases. However, caring for children particularly with DMD and OI was burdensome because of daily practical problems (bathing, toileting), increased time costs and social isolation, as reported in studies on other RGDs [70-72]. Consequently, carers reported lower QOL particularly in critical periods of loss of ambulation in boys with DMD and during the occurrence of fractures in OI as recently confirmed [73].

As for the QOL in patients with these three diseases, findings seem contradictory with some publications reporting higher QOL and other reporting lower QOL when compared to healthier unaffected controls [20,22]. The severity of functional and physical impairments follow the severity of the disease, and could be seen as increasing from small functional impairment, such as back pain in achondroplasia, to restricted ambulation from bone deformities and numerous fractures in OI, to progressively reduced ambulation and confinement to a wheelchair in DMD [22]. On the contrary and strikingly, the psychological aspect of QOL in patients did not parallel the severity of the disease. For example, DMD is lifethreatening and its psychosocial impacts are expected to be more severe than for achondroplasia and OI; however, patients with OI did not seem to experience less psychological distress than those with DMD [41,69]. As for the course of the disease, the stable (unchanged) level of psychological distress in patients with achondroplasia reflects the non-progressive course of the disease [13]. The "up and down" pattern of psychological distress in patients with severe OI also confirms the occurrence of fractures as critical periods over the chronic course of OI [73]. While functional limitations increased, the self-reported psychosocial QOL of boys with DMD did not decrease with age. They may have developed effective coping strategies that ought to have been better documented [52]. This finding was confirmed in previous studies. Indeed the level of impact on family including psychological stress was high for families who had children affected by rare genetic metabolic conditions even when the child's function was not impaired and the disease was not severe [5].

Some practical implications emerged from this review that can benefit families and caregivers. The correlation between improved parental coping strategies and early diagnosis, better emotional functioning of the child and siblings suggests that there have been efforts to obtaining an early diagnosis and promoting family hardiness for people living with these diseases $[74,75]$. To that end, interprofessional teams of geneticists, psychologists and social workers in reference centers for these rare diseases could be effective by offering newborn screening, familycentered and life-span psychosocial support whenever possible [76]. Besides, informal support from family and friends but also institutional health and social support 
Table 4 Summary of the findings of publications on non-medical impacts of DMD

\begin{tabular}{|c|c|c|c|c|c|}
\hline Publication & Major findings & Domain & Instruments used & Sample (N) & Country \\
\hline Baiardini, Minetti et al. [19] & $\begin{array}{l}\text { Using the Children's Health Questionnaire, children with DMD } \\
\text { were significantly limited in performing physical activities and } \\
\text { demonstrated difficulties with school and other daily activities. } \\
\text { The family dynamic appeared to remain intact, but some } \\
\text { parents and caregivers reported problems with social aspects } \\
\text { of their life. }\end{array}$ & $\mathrm{QOL}$ & $\begin{array}{l}\text { Children Health Questionnaire-Parent } \\
\text { Form 50, Family Strain Questionnaire }\end{array}$ & $\begin{array}{l}21 \text { mothers, } \\
6 \text { fathers or } \\
\text { DMD patients }\end{array}$ & Italy \\
\hline Bray, Bundy et al. [22] & $\begin{array}{l}\text { Parents of boys with DMD reported significantly poorer health } \\
\text { and physical functioning than healthy controls. Parents reported } \\
\text { that transitioning to a wheelchair was a particularly difficult time. }\end{array}$ & $\mathrm{QOL}$ & Child Health Questionnaire (CHQ-PF50) & $\begin{array}{l}34 \text { boys with } \\
\text { DMD, } 17 \text { parents } \\
\text { at follow up }\end{array}$ & Australia \\
\hline Bray, Bundy et al. [23] & $\begin{array}{l}\text { Boys with DMB reported significantly lower health-related } \\
\text { quality of life compared to the general population, with a } \\
\text { moderate to poor correlation with reports from their parents, } \\
\text { with parents generally underestimating quality of life } \\
\text { of their sons. }\end{array}$ & $\mathrm{QOL}$ & $\begin{array}{l}\text { Pediatric Quality of Life } \\
\text { Inventory (PedsQLI) }\end{array}$ & $\begin{array}{l}35 \text { parent-son } \\
\text { dyads of boys } \\
\text { with DMD }\end{array}$ & Australia \\
\hline Uzark, King et al. [52] & $\begin{array}{l}\text { QOL scores for boys with DMD were significantly lower than } \\
\text { those for healthy children for physical and psychosocial QOL. } \\
\text { Psychosocial QOL scores were highly impaired particularly in } \\
\text { older patients and not significantly associated with use of } \\
\text { mobility aids. }\end{array}$ & $\mathrm{QOL}$ & $\begin{array}{l}\text { PedsQL } 4.0 \text { Generic Core and } \\
\text { DMD Module Scales }\end{array}$ & $\begin{array}{l}203 \text { families of } \\
\text { boys with DMD }\end{array}$ & USA \\
\hline Kohler, Clarenbach et al. [41] & $\begin{array}{l}\text { Patients with DMD reported a high level of perceived quality } \\
\text { of life. Despite severe limitations in physical functioning, } \\
\text { patients reported less role limitations, physical and mental } \\
\text { problems, and coping abilities. }\end{array}$ & $\mathrm{QOL}$ & $\begin{array}{l}\text { Medical Outcome Questionnaire } \\
\text { Short Form } 36 \text { (SF-36) }\end{array}$ & $\begin{array}{l}35 \text { male patients } \\
\text { with } \mathrm{DMD}\end{array}$ & Switzerland \\
\hline Manzur, Kinali et al. [42] & $\begin{array}{l}\text { There have been improvements in general care and treatment } \\
\text { modalities for patients with DMD, with survival into adulthood } \\
\text { now a possibility. Multidisciplinary and holistic treatment } \\
\text { approaches are also recommended. Curative therapeutic } \\
\text { strategies such as cell and gene therapy are currently } \\
\text { experimental. }\end{array}$ & $\mathrm{QOL}$ & N/A - Literature Review & $\mathrm{N} / \mathrm{A}$ & UK \\
\hline Simon, Resende et al. [50] & $\begin{array}{l}\text { Comparing different age groups, patients with DMD did not } \\
\text { lose QOL, even with disease progression. In spite of the } \\
\text { progressive course of the disease, the QOL in patients } \\
\text { with DMD does not worsen. }\end{array}$ & $\mathrm{QOL}$ & $\begin{array}{l}\text { Life Satisfaction Index for } \\
\text { Adolescents (LSI-A) }\end{array}$ & $\begin{array}{l}95 \text { patients } \\
\text { with } \mathrm{DMD}\end{array}$ & Brazil \\
\hline Garralda, Muntoni et al. [32] & $\begin{array}{l}\text { Parents with children with KAFOS reported satisfaction with } \\
\text { the rehabilitation process, but some expressed a desire to } \\
\text { have had more information beforehand. Families of } \\
\text { children with more severe disability reported higher levels } \\
\text { of mental distress during the process. }\end{array}$ & $\begin{array}{l}\text { Functional } \\
\text { limitations }\end{array}$ & $\begin{array}{l}\text { Life Satisfaction Index for } \\
\text { Adolescents (LSI-A) }\end{array}$ & $\begin{array}{l}17 \text { parents } \\
\text { and } 9 \text { children } \\
\text { with DMD }\end{array}$ & UK \\
\hline Bendixen, Senesac et al. [20] & $\begin{array}{l}\text { When compared with unaffected controls, boys with DMD } \\
\text { displayed significantly lower participation in both physical } \\
\text { and social activities. Boys with DMD also demonstrated } \\
\text { significantly lower QOL scores for physical, social, and } \\
\text { school-related domains. }\end{array}$ & $\begin{array}{l}\text { Functional } \\
\text { limitations }\end{array}$ & $\begin{array}{l}\text { Semi-structured interviews, Functional } \\
\text { Disability Inventory (FDI), The Strengths } \\
\text { and Difficulties Questionnaires (SDQ), } \\
\text { General Health Questionnaire (GHQ-28), } \\
\text { Impact of Events Scale (IES) }\end{array}$ & $\begin{array}{l}50 \text { boys with DMD; } \\
25 \text { unaffected } \\
\text { aged-matched } \\
\text { controls }\end{array}$ & USA \\
\hline
\end{tabular}


Table 4 Summary of the findings of publications on non-medical impacts of DMD (Continued) associated with dysphagia inc

coughing while eating, choking while eating, and the need

to clear the throat. This demonstrated that a significant

portion of patients with DMD had swallowing-related

symptoms into their teenage years.

Marini, Lorusso et al. [43]_The DMD group demonstrated reduced abilities in language processing and cognition, specifically visual attention, but not in receptive or expressive lexical abilities. As well, the narrative speech in subjects with DMD was reduced compared to controls, with shorter sentences.

van Wijk, Messelink et al. [53] Lower urinary tract symptoms in DMD patients are underreported and underdiagnosed; however, the vast majority of male DMD patients with symptoms experience them as a problem, often reducing quality of life.

Read, Kinali et al. [48]

Unaffected siblings demonstrated comparative psychological functioning and wellbeing scores; however, there was a trend towards increased risk for psychological and emotional problems. Siblings also reported a high impact of their affected sibling's illness on their lives.

Read, Kinali et al. [49]

Kenneson and Bobo [39]

Siblings reported feeling left out when the affected sibling required extra attention, yet the majority remained psychologically well adjusted.

About half of the caregivers experienced a high level of caregiving demand based on the abbreviated four-item ZB consistent with previous report using the full ZBI scale.

James, Hadley et al. [35]

Guilt in parents of those with disabilities is associated with depression, helplessness, hopelessness, and disruption of depression, helplessness, hopelessness, and disruption of Xe cond parenting. Maternal guilt appears common in $\mathrm{XL}$ conditions. Understanding reproductive risks had no significant impact on level of worry among all family members implies that, at least for fathers, siblings, and affected adults, worry is related less to empiric risks and understanding of those risks than to the experience of having an affected family member.

Hendriksen, Poysky et al. [34] The results demonstrate the PARS-III is a reliable and valid measure for screening psychosocial adjustment for individuals with DMD. As well, older patients demonstrated higher overall psychosocial adjustment
Functiona

limitations

Children's Assessment of Participation

Childen's Assessment of Participation

31 males

Life Inventory TM 4.0

with DMD

Functional limitations

Survey of swallowing related symptoms (modified version of previously published measure)

21 males with

DMD, 40 healthy

controls

Functional

limitations

Assessment of narrative abilities

199 patients

with DMD

Netherland

using the "Nest Story"

46 unaffected

siblings of children

Strengths and Difficulties Questionnaire

(SDQ), General Health Questionnaire

with DMD

impacts

Scale (HADS), SF-36, Functional

Disability Inventory (FDI), Family

Assessment Device (FAD), Family

Burden Interview Schedule and Life

Events Checklist

and published by the authors.

51 families with chronic

families with DMD
Psychological

impacts

Semi-structured interviews and

questionnaires previously developed

Psychological

impacts

Survey, components from: Johnson \&

Johnson Stress Profile, Kessler (K6)

Behavioral Risk Factor Surveillance

System (BRFSS), Zarit Burden

Interview (ZBI), Brief Resilient Coping

Scale, ENRICHD Social Support

Instrument (ESSI)

Psychological Questionnaire developed by authors

impacts

112 members of

granulomatous; 96

members of 5

Psychologica

Personal Adjustment and Role Skills

Scale (PARs-III), Revised Rutter Scale

35 sibling/parent dyads of children

1238 Woman

caregivers for

individuals

with DBMD

impacts
Netherlands, 
Table 4 Summary of the findings of publications on non-medical impacts of DMD (Continued)

\begin{tabular}{|c|c|c|c|c|c|}
\hline $\begin{array}{l}\text { Abi Daoud, Dooley } \\
\text { et al. [16] }\end{array}$ & $\begin{array}{l}\text { Parents with a son with DMD were more likely to have } \\
\text { an episode of major depression and to have consulted } \\
\text { a mental health professional during the last year, and to } \\
\text { demonstrate lower self- esteem, than parents in a control group. }\end{array}$ & $\begin{array}{l}\text { Psychological } \\
\text { impacts }\end{array}$ & $\begin{array}{l}\text { Depression Scale comprised of } \\
\text { items from the World Health } \\
\text { Organization's Composite } \\
\text { International Diagnostic Interview Short } \\
\text { Form (CIDI-SF) }\end{array}$ & $\begin{array}{l}42 \text { parents from } \\
26 \text { families } 27 \text { males } \\
\text { with DMD }\end{array}$ & Canada \\
\hline Chen [24] & $\begin{array}{l}\text { Parents of children who were diagnosed at an earlier age } \\
\text { reported an increase in ability to cope as a family. Child's } \\
\text { level of disability and family hardiness was not correlated } \\
\text { to level of family function. }\end{array}$ & $\begin{array}{l}\text { Psychological } \\
\text { impacts }\end{array}$ & $\begin{array}{l}\text { Family Hardiness Index, Family } \\
\text { Assessment Device, Family APGAR, } \\
\text { Duke Health Profile }\end{array}$ & $\begin{array}{l}126 \text { parents of } \\
\text { children with } \mathrm{DMD}\end{array}$ & Taiwan \\
\hline Chen, Chen et al. [25] & $\begin{array}{l}\text { Parents with a child with DMD were more aggressive about } \\
\text { obtaining resources for their child, with higher stress levels } \\
\text { for mothers, and families with a lower income. Coping } \\
\text { strategies were used more often in mothers, but overall, } \\
\text { fewer coping strategies for emotional expression, self-blame, } \\
\text { information seeking, and threat minimization were made. }\end{array}$ & $\begin{array}{l}\text { Psychological } \\
\text { impacts }\end{array}$ & $\begin{array}{l}\text { Chronic Impact and Coping Instrument } \\
\text { (CICl); Subscales of the Felton } 1984 \\
\text { Coping Scale }\end{array}$ & $\begin{array}{l}31 \text { parents of } \\
\text { children with DMD, } \\
30 \text { control parents }\end{array}$ & Taiwan \\
\hline Chen and Clark [27] & $\begin{array}{l}\text { Parents' employment and education, as well as perceived } \\
\text { child health and family hardiness/support, was correlated } \\
\text { with parental health. Promotion of family hardiness can be } \\
\text { supported by nursing interventions and caregiving programs. }\end{array}$ & $\begin{array}{l}\text { Psychological } \\
\text { impacts }\end{array}$ & Family APGAR & $\begin{array}{l}126 \text { parents of } \\
\text { children with } \mathrm{DMD}\end{array}$ & Taiwan, USA \\
\hline $\begin{array}{l}\text { Garralda, McConachie } \\
\text { et al. [31] }\end{array}$ & $\begin{array}{l}\text { Most families reported a positive emotional impact from } \\
\text { the trial, with minimal negative impact. Families reported } \\
\text { having adequate knowledge and information about the } \\
\text { study. Some families reported negative impacts and } \\
\text { disappointments during the trial when their child's } \\
\text { health deteriorated. }\end{array}$ & $\begin{array}{l}\text { Psychological } \\
\text { impacts }\end{array}$ & $\begin{array}{l}\text { Parental Stress and Supports } \\
\text { Questionnaire (PSSQ), General Health } \\
\text { Questionnaire (GHQ-28), Strengths and } \\
\text { Difficulties Questionnaire (SDQ) }\end{array}$ & $\begin{array}{l}19 \text { children with } \\
\text { DMD and their } \\
\text { families }\end{array}$ & UK \\
\hline Chen and Clark [26] & $\begin{array}{l}\text { There were significant correlations between age at } \\
\text { diagnosis and family function, with better outcomes } \\
\text { associated with a younger age at diagnosis. As well, } \\
\text { the level of the child's disability was not associated } \\
\text { with family function. However, parents did report poorer } \\
\text { overall health and an increase in anxiety, depression, and } \\
\text { pain and disability, compared to the general population. }\end{array}$ & $\begin{array}{l}\text { Psychological } \\
\text { impacts }\end{array}$ & $\begin{array}{l}\text { Barthel Index, Chinese version of Duke } \\
\text { Health Profile 27, Family APGAR28, } \\
\text { The Family Hardiness Index13, } \\
\text { McMaster Family Assessment } \\
\text { Device (FAD). }\end{array}$ & $\begin{array}{l}8 \text { single fathers, } \\
26 \text { single mothers, } \\
46 \text { couples with } \\
\text { children with DMD }\end{array}$ & USA \\
\hline Parsons, Clarke et al. [46] & $\begin{array}{l}\text { Prenatal screening for DMD was supported by most families, } \\
\text { however anxiety levels for the screened group was higher. }\end{array}$ & $\begin{array}{l}\text { Psychological } \\
\text { impacts }\end{array}$ & $\begin{array}{l}\text { Structured question developed by } \\
\text { authors, FIRST scores, State Scale, } \\
\text { General Health Questionnaire (GHQ) }\end{array}$ & $\begin{array}{l}20 \text { families } \mathrm{w} / \text { child } \mathrm{W} / \\
\mathrm{DMD}, 18 \text { transient, } \\
16 \text { control w/ later } \\
\text { diagnosis, } 43 \text { control } \\
\text { W/ no diagnosis }\end{array}$ & UK \\
\hline Cyrulnik, Fee et al. [28] & $\begin{array}{l}\text { By parental report, children with DMD demonstrated } \\
\text { significant delays in adaptive behaviour skills. Children } \\
\text { with DMD also performed more poorly on } \\
\text { neuropsychological tests. }\end{array}$ & $\begin{array}{l}\text { Psychological } \\
\text { impacts }\end{array}$ & $\begin{array}{l}\text { Vineland Adaptive Behavior Scales, } \\
\text { Peabody Picture Vocabulary Test }\end{array}$ & $\begin{array}{l}20 \text { children with } \\
\text { DMD, } 20 \text { controls }\end{array}$ & USA \\
\hline Fee, Hinton et al. [29] & $\begin{array}{l}\text { Children living with DMD demonstrated strong behavioural } \\
\text { resiliency, which was correlated to high social support } \\
\text { and social networks. }\end{array}$ & $\begin{array}{l}\text { Psychological } \\
\text { impacts }\end{array}$ & $\begin{array}{l}\text { Child Behavior Checklist (CBCL), } \\
\text { Parental Stress Index }\end{array}$ & 146 boys with $\mathrm{DMD}$ & USA \\
\hline
\end{tabular}


Table 4 Summary of the findings of publications on non-medical impacts of DMD (Continued)

Firth, Gardnermedwin

et al. [30]

Pangalila, van den Bos et al. 2012 [44]

Pehler and Craft-Rosenberg $2009[47]$

Beresford and Sloper $2003[21]$

Steele, Taylor et al. 2008 [51] Half of the children have attention deficit-hyperactivity disorder ADHD, which has not been reported in the literature. In the area of internalizing disorders, none of these patients met criteria for depression, either on the KSADS or the self-administered CDI.

Arias, Andrews et al. 2011 [18] Fewer than 1 in 5 families were familiar with the term "palliative care", and less than a third had legal plans or advanced directives in place.

Acharya, Ackerman et al. $2005[17]$

Parker, Robb et al. 2005 [45] While adult patients with DMD deal with a progressive physical impairment due to respiratory, orthopaedic and other medical factors, areas of disability with often overlooked importance were found in areas of social and medical support. hut are less supportive of expanding screen screening. Willingness to expand newbo screening does not correlate with professional characteristics but rather with personal interest in
Guided interviews developed

Illness

experiences

by the authors

56 affected boys,

53 families of boys

with DMD

IIness

experiences

Caregiver Strain Index (CSI), Self Rated Burden Scale, The EuroQoL-5D,

Hospital Anxiety and Depression Scale

(HADS), Utrecht Coping List (UCL).

General Self-Efficacy Scale

IIIness

Interview using Manen's

Phenomenological method

80 parents of 57 adults with DMD

Netherlands

experiences

Semi-structured interviews and group discussion meetings.

9 adolescent boys with DMD

63 chronically i adolescents

experiences

The Schedule for Affective Disorders and Schizophrenia for School-Age

Children (KSADS), Revised Children's

assessment of

mental health

Manifest Anxiety Scale (RCMAS), Children's

Depression Inventory (CDI), Piers-Harris

Children's Self- Concept Scale, Wechsler Intelligence Scale for Children: Third

Edition (WISC-III), KSADS-Parent Version,

Child Behavior Checklist (CBCL),

Conners' Parent Rating Scale

Other, use of Structured questionnaire developed by palliative care authors through focus groups and stakeholder discussions

34 parents of

children

with DMD

Other, attitudes Survey developed by authors

600 paediatricians of staff

Other Retrospective review 
Table 4 Summary of the findings of publications on non-medical impacts of DMD (Continued)

\begin{tabular}{|c|c|c|c|c|c|}
\hline Kinali, Manzur et al. 2006 [40] & $\begin{array}{l}\text { The survey on the attitudes and practices of UK physicians } \\
\text { demonstrated that physicians accept and implement NIV } \\
\text { to DMD patients. As well most physicians reported that } \\
\text { they promoted shared decision making with DMD } \\
\text { patients with respect to NIV. There was also a lack in } \\
\text { uniformity of opinion concerning long-term respiratory } \\
\text { follow-up for DMD. }\end{array}$ & $\begin{array}{l}\text { Other, attitudes } \\
\text { of staff }\end{array}$ & $\begin{array}{l}\text { Modified version of a previously } \\
\text { published questionnaire }\end{array}$ & 59 physicians & Canada, UK \\
\hline $\begin{array}{l}\text { Vandervelde, Van den Bergh } \\
\text { et al. } 2009 \text { [54] }\end{array}$ & $\begin{array}{l}\text { The ACTIVLIM questionnaire showed a good sensitivity } \\
\text { to change and could be useful in research settings to } \\
\text { characterize the disease course of NMD. }\end{array}$ & Other & ACTIVLIM Questionnaire & $\begin{array}{l}132 \text { patients } \\
\text { with NMD }\end{array}$ & Belgium \\
\hline Jutai, Rigby et al. 2000 [37] & $\begin{array}{l}\text { Our research provides good evidence to support the } \\
\text { claim that EADLs (Electronic Aids to Daily Living) } \\
\text { contribute significantly to the user's perceived functional } \\
\text { independence. Moreover, EADLs appear to enhance } \\
\text { other important aspects of the user's psychological } \\
\text { well-being, such as feelings of self-confidence and } \\
\text { perceived control. }\end{array}$ & $\begin{array}{l}\text { Other, use } \\
\text { of electronic } \\
\text { device }\end{array}$ & $\begin{array}{l}\text { Psychosocial Impact of Assistive } \\
\text { Devices Scale (PIADS) }\end{array}$ & $\begin{array}{l}20 \text { users of EADLs } \\
\text { and } 21 \text { non-users }\end{array}$ & Canada \\
\hline $\begin{array}{l}\text { Jarvinen, Lehesjoki et al. } \\
2000 \text { [36] }\end{array}$ & $\begin{array}{l}\text { Carrier testing was in most cases correctly understood and } \\
\text { the matter openly discussed. Our results do not suggest } \\
\text { that testing in childhood had caused serious harm to } \\
\text { the young individuals tested. On the other hand, we } \\
\text { found no obvious benefits from this early testing. }\end{array}$ & Other & $\begin{array}{l}\text { Questionnaire developed by authors, } \\
\text { RAND 36-item Health Survey } 1.0\end{array}$ & $\begin{array}{l}23 \text { female carries of } \\
\text { DMD, } 23 \text { females } \\
\text { in families with } \\
\text { haemophilia }\end{array}$ & Finland \\
\hline Kemper and Wake 2007 [38] & $\begin{array}{l}\text { Evidence for routine newborn screening for DMD was } \\
\text { reviewed, without sufficient data to make a strong } \\
\text { recommendation. Further research in the areas of cost, } \\
\text { risks, and benefits needs to be conducted. }\end{array}$ & $\begin{array}{l}\text { Other, attitudes } \\
\text { towards newborn } \\
\text { screening }\end{array}$ & Literature review & & Australia, USA \\
\hline
\end{tabular}


Table 5 Summary of findings of publications on non-medical impacts of osteogenesis imperfecta

\begin{tabular}{lll}
\hline Publication Major findings Domain &
\end{tabular}

Instruments used
SF-36

Sample (N)

Country

Balkefors, Mattsson et al. [55] Life satisfaction was high even though health-related quality of life, assessed QOL with the Short Form 36, was significantly lower than the Swedish norm.

Kok, Uiterwaal et al. [61]

We found little difference in quality of life between the bisphosphonate and QOL placebo groups however in favour of the bisphosphonate group during the two-year follow-up.

Seikaly, Kopanati et al. $2005[63]$

These studies showed a correlation between the severity of the phenotypic expression of $\mathrm{Ol}$ and $\mathrm{QOL}$ indicators tested. Reduced pain, besides being by itself an advantageous outcome, allows effective physical therapy and by itself an advantageous outcome, allows effective physical therapy and
weight bearing, both benefits that help further strengthen bone. We speculate that improvement in pain resulted in a better sense of well- being and subsequently better self-care scores.

Szczepaniak-Kubat, The child's disease did not significantly affect either the global quality of Kurnatowska et al. 2012 [65] life assessment or health of the respondents or their quality of life in terms of physical and psychological status and social relationships. The parents of children with severe Ol assessed the life domain associated with the environment they live in as worse than the parents of children with mild Ol. The global quality of life assessment of the respondents did not depend on the family's socioeconomic status or on the help they have been receiving with regard to care for the child.

Widmann, Laplaza et al. $2002[68]$

Widmann, Bitan et al. 1999 [69]

Cole $1993[58]$

Suskauer, Cintas et al. 2003 [64]

Bernehall Claesson and Brodin 2002 [56]

Brodin $1993[57$
The results of the SF-36 revealed significantly lower physical function scores compared to the U.S. adult norms. However, the SF-36 mental component scores were equal to the U.S. adult norms. The demographic questionnaire revealed high levels of educational achievement, as well as employment, despite significant physical impairments. The functional questionnaire clearly demonstrated limitations mostly related to ambulation.

Physical health as assessed by the SF-36 was closely correlated with vital capacity and scoliosis. Mental health status (assessed by the SF-36 MCS) was not significantly correlated with spinal deformity, chest wall deformity, or pulmonary compromise.

Psychological aspects studied in a chronologic manner. Impacts on parents, patients, siblings mentioned. Challenges at school, in the society, for the healthcare professionals. Severe, mild and family cases are mentioned.

The data suggest that children with OI differ only to the extent that they are relatively hypoactive, and the temperament domains of activity, persistence, and first reaction (approach/withdrawal) may be particularly important for promoting motor achievement

Families with children with BBD face many difficulties such as accusations of child abuse, lack of support, and lack of information on the disease. Family activities and family dynamics are also affected by re-occurring fractures and many parents become overprotective.

For children growing up with brittle bones and their families the living conditions are sometimes complicated as they cannot participate in social life together with other young people. Parents of
Database review

29 adults

Sweden

54 children with $\mathrm{Ol}$

PEDI, WeeFIM, Bone Mineral Density (BMD)

7 children W/ type III and IV OI

WHOQOL-BREF, International Standard Classification of Education (ISCED) Family Affluence Scale (FAS)

25 parents of children with OI
SF-36, Functional Independence Measure (FIM)

Questionnaire developed by authors, Short Form-36 (SF-36)

5 patients with $\mathrm{Ol}$

Psychological N/A - Opinion paper impacts

Psychological impacts

Illness

experience

IIIness experience
Carey Temperament Scales, Brief Assessment of Motor Function (BAMF) VCOPS, CHAQ, PDH, Pediatric Activity Record (PAR) based on their previous studies interviews based on the questionnaire (a) W/ children w/ BBD

42 families Questionnaires developed by author and previously published
Questionnaire developed by authors, 
Table 5 Summary of findings of publications on non-medical impacts of osteogenesis imperfecta (Continued)

\begin{tabular}{|c|c|c|c|c|c|}
\hline & $\begin{array}{l}\text { disabled children often complain that their anxieties have been ignored } \\
\text { by professionals. No one seems to take them seriously. They have little } \\
\text { psychological support and many parents need merely a person to talk to. } \\
\text { In order to facilitate habilitation of the child, support should be given } \\
\text { to the whole family. }\end{array}$ & & & & \\
\hline $\begin{array}{l}\text { Daly, Wisbeach et al. } \\
1996 \text { [59] }\end{array}$ & $\begin{array}{l}\text { The prognosis for walking in Ol was assessed by questionnaire, finding } \\
\text { five different patterns of development: abnormal/arrested, delayed/arrested, } \\
\text { delayed, and normal. The Sillence and Shapiro classifications were useful } \\
\text { in predicting walking. Intramedullary rodding was not advised if the } \\
\text { patients had a delay solely in motor development. }\end{array}$ & $\begin{array}{l}\text { Functional } \\
\text { limitations }\end{array}$ & Questionnaire developed by authors & $\begin{array}{l}59 \text { families } \\
\text { of children } \\
\text { with Ol }\end{array}$ & UK \\
\hline $\begin{array}{l}\text { Engelbert, Uiterwaal et al. } \\
2000 \text { [60] }\end{array}$ & $\begin{array}{l}\text { As a predictor of ability to walk in a household, type of Ol is the best, } \\
\text { along with severity of the collagen defect, and the presence of } \\
\text { dentinogenesis imperfecta. Intramedullary rods in the lower } \\
\text { extremities have a worse prognosis for walking. }\end{array}$ & $\begin{array}{l}\text { Functional } \\
\text { limitations }\end{array}$ & Questionnaire developed by authors & $\begin{array}{l}76 \text { children } \\
\text { with Ol }\end{array}$ & Netherlands \\
\hline $\begin{array}{l}\text { Montpetit, Dahan-Oliel et al. } \\
2011 \text { [61] }\end{array}$ & $\begin{array}{l}\text { Young adults with OI type III had significantly lower activity scores in } \\
\text { aspects of mobility and domestic life and lower levels of participation } \\
\text { in employment, sporting activities and transportation. Participation in } \\
\text { leisure and social interactions were not different across Ol types. }\end{array}$ & $\begin{array}{l}\text { Functional } \\
\text { limitations }\end{array}$ & $\begin{array}{l}\text { Modified questionnaire including scales } \\
\text { of the Functional Independence Measure } \\
\text { (FIM) and Instrumental Activities } \\
\text { Measure (IAM) }\end{array}$ & $\begin{array}{l}54 \text { former } \\
\text { Ol patients }\end{array}$ & Canada \\
\hline $\begin{array}{l}\text { Van Brussel, Takken et al. } \\
2008 \text { [67] }\end{array}$ & $\begin{array}{l}\text { A supervised training program can improve aerobic capacity and muscle } \\
\text { force and reduces levels of subjective fatigue in children with OI type I } \\
\text { and IV in a safe and effective manner. }\end{array}$ & $\begin{array}{l}\text { Functional } \\
\text { limitations after } \\
\text { physical training }\end{array}$ & $\begin{array}{l}\text { Checklist Individual Strength-20 (CIS-20), } \\
\text { Self-perception Profile for Children (CBSK), } \\
\text { Child Health Questionnaire Parent-Form } \\
50 \text { (CHQ) }\end{array}$ & $\begin{array}{l}34 \text { children } \\
\text { with Ol }\end{array}$ & Netherlands \\
\hline Tolboom, Cats et al. 2004 [66] & $\begin{array}{l}\text { The present study demonstrated a non-significant, but clinically important } \\
\text { increase in self-care with a decrease in caregiver assistance regarding } \\
\text { self-care after spinal surgery. }\end{array}$ & $\begin{array}{l}\text { Functional } \\
\text { limitations } \\
\text { after surgery }\end{array}$ & $\begin{array}{l}\text { Harter Self-Perception Profile for Children } \\
\text { (SPPC), Paediatric Evaluation of Disability } \\
\text { Inventory (PEDI) }\end{array}$ & $\begin{array}{l}11 \text { children } \\
\text { with } \mathrm{Ol}\end{array}$ & Netherlands \\
\hline
\end{tabular}


such as respite care can contribute to the relief of the burden of care on families.

From the limited number of publications on the impacts of DMD, achondroplasia and OI, we have learned that research about non-medical impacts of achondroplasia, DMD and OI on healthcare systems and society seems very limited and could be further addressed. However, the selection of the keywords used in the searching strategy in this review might have resulted in the exclusion of some publications. For example, challenges in providing adequate updating training to clinicians and staff on these rare diseases as acknowledged in other RGDs could be examined. In addition, research on healthcare-related impacts might compare the use of healthcare resources according to the severity of the disease. Efficient care delivery models organised around primary care whereby family physicians can help to achieve a smooth transition to adult care institutions must also be investigated [56,77,78]. In addition more theoretical understanding is needed about the complex and non-linear interrelationships between two aspects of QOL: the available quality of care and the family functioning and economic status [79-81]. Such understanding will help to acknowledge the relative impacts of these determinants on overall QOL and will help to prioritize adequate interventions.

We acknowledge that methodological limitations could have compromised the inclusion of publications reviewed here. Thus, further longitudinal studies combining normative approaches with qualitative in-depth investigations and comparing several diseases could enhance the understanding of patients' effective coping strategies. Simultaneous use of parent-report and patient-report questionnaires could provide increased insights [22]. Furthermore, our inhouse working framework that guided our organization and analysis of the scoping review could aid others in mapping and organizing the literature during a scoping review; however, to extend its use beyond this would require further validation.

\section{Conclusion}

In general, DMD and OI negatively impacted carers. Some events seem particularly critical such as occurrence of fractures or loss of ambulation in patients. As for patients, functional limitations seemed to follow the severity of the disease, but psychological distress did not, which calls for a better understanding of effective coping strategies. This conclusion is supported by the reported higher life satisfaction in very severely affected patients at different stages of the progressing course of DMD, and the reported resilience characteristic of adolescents with OI. In face of the great difficulties presented to families, life span and family-centered psychological support must be developed in a timely fashion to aid patients, carers, and siblings.

\section{Abbreviations}

DMD: Duchenne muscular dystrophy; Ol: Osteogenesis imperfecta; QOL: Quality of life; RGD(s): Rare genetic disease(s).

\section{Competing interests}

Authors declare no competing interests.

\section{Authors' contributions}

MJD conceived the study, performed the literature review, drafted the initial manuscript and approved this version as submitted. FR conceived the study, critically revised the manuscript and approved this version as submitted. ED performed the literature review and approved this version as submitted. CB critically revised the manuscript and approved this version as submitted.

\section{Acknowledgements}

This study was supported by the Shriners of North America; the Network for Oral and Bone Health Research (RSBO), which receives funding from the Fonds de la Recherche du Québec-Santé (FRQ-S); and the MENTOR program, which receives funding from the Canadian Institutes of Health Research. FR received support from the Chercheur-Boursier Clinicien program of the Fonds de recherche Québec-Santé. These sponsors had no involvement in determining the content of this paper. We also thank Susan Lemprière and Judith Kashul for editorial revision.

\section{Author details}

'Shriners Hospital for Children, 1529 Cedar Avenue, H3G 1 A6 Montreal, QC, Canada. ${ }^{2}$ Department of family and emergency medicine, Faculty of Medicine, Université Laval, 1050 Medicine Avenue, Quebec G1V0A6, Canada. ${ }^{3}$ Faculty of Dentistry, McGill University, 3550 University Street, H3A 2A7 Montreal, QC, Canada. ${ }^{4}$ Department of Social and Preventive Medicine, Faculty of Medicine, Université de Montréal, H3C 3 J7, C.P. 6128, Succ. Centre-Ville, Montreal, QC, Canada.

Received: 18 February 2014 Accepted: 6 October 2014

Published online: 25 October 2014

\section{References}

1. Schieppati A, Henter Jl, Daina E, Aperia A: Why rare diseases are an important medical and social issue. Lancet 2008, 371:2039-2041.

2. Ayme S, Kole A, Groft S: Empowerment of patients: lessons from the rare diseases community. Lancet 2008, 371:2048-2051.

3. Kole A, Faurisson F: The Voice of 12,000 Patients: Experiences and expectations of rare disease patients on diagnosis and care in Europe. Eurodisth edition; 2009.

4. Wallander JL, Varni JW: Effects of pediatric chronic physical disorders on child and family adjustment. J Child Psychol Psychiatry 1998, 39:29-46.

5. Anderson M, Elliott EJ, Zurynski YA: Australian families living with rare disease: experiences of diagnosis, health services use and needs for psychosocial support. Orphanet J Rare Dis 2013, 8:22.

6. Shahbazi S, Moghaddam-Banaem L, Ekhtesari F, Ala FA: Impact of inherited bleeding disorders on pregnancy and postpartum hemorrhage. Blood Coagul Fibrinolysis 2012, 23:603-607.

7. Boekaerts $M$, Roder I: Stress, coping, and adjustment in children with a chronic disease: a review of the literature. Disabil Rehabil 1999, 21:311-337.

8. Levac D, Colquhoun H, O'Brien KK: Scoping studies: advancing the methodology. Implement Sci 2010, 5:69.

9. Daudt HM, van Mossel C, Scott SJ: Enhancing the scoping study methodology: a large, inter-professional team's experience with Arksey and O'Malley's framework. BMC Med Res Methodol 2013, 13:48.

10. Brien SE, Lorenzetti DL, Lewis S, Kennedy J, Ghali WA: Overview of a formal scoping review on health system report cards. Implementation Science 2010, 5:2.

11. Arksey H, O'Malley L: Scoping studies: towards a methodological framework. Int J Soc Res Methodol 2005, 8:19-32.

12. Saldaña J: The Coding Manula for Qualitative Researchers. Los Angeles: Sage Publications; 2013.

13. Ain MC, Abdullah MA, Ting BL, Skolasky RL, Carlisle ES, Schkrohowsky JG, Rigamonti D: Progression of low back and lower extremity pain in a 
cohort of patients with achondroplasia. J Neurosurg Spine 2010, 13:335-340.

14. Gollust SE, Thompson RE, Gooding HC, Biesecker BB: Living with achondroplasia: attitudes toward population screening and correlation with quality of life. Prenat Diagn 2003, 23:1003-1008.

15. Kim S-J, Balce GC, Agashe MV, Song S-H, Song H-R: Is bilateral lower limb lengthening appropriate for Achondroplasia? Midterm analysis of the complications and quality of life. Clin Orthop Relat Res 2012, 470:616-621.

16. Abi Daoud MS, Dooley JM, Gordon KE: Depression in parents of children with Duchenne muscular dystrophy. Pediatr Neurol 2004, 31:16-19.

17. Acharya K, Ackerman PD, Ross LF: Pediatricians' attitudes toward expanding newborn screening. Pediatrics 2005, 116:E476-E482.

18. Arias R, Andrews J, Pandya S, Pettit K, Trout C, Apkon S, Karwoski J, Cunniff C, Matthews D, Miller T, Davis MF, Meaney FJ: Palliative care services in families of males with Duchenne muscular dystrophy. Muscle Nerve 2011, 44:93-101.

19. Baiardini I, Minetti C, Bonifacino S, Porcu A, Klersy C, Petralia P, Balestracci S, Tarchino F, Parodi S, Canonica GW, Braido F: Quality of life in Duchenne muscular dystrophy: the subjective impact on children and parents. J Child Neurol 2011, 26:707-713.

20. Bendixen RM, Senesac C, Lott DJ, Vandenborne K: Participation and quality of life in children with Duchenne muscular dystrophy using the International Classification of Functioning, Disability, and Health. Health Qual Life Outcomes 2012, 10:43.

21. Beresford BA, Sloper P: Chronically ill adolescents' experiences of communicating with doctors: a qualitative study. J Adolesc Health 2003, 33:172-179.

22. Bray P, Bundy AC, Ryan MM, North KN, Burns J: Health status of boys with Duchenne muscular dystrophy: a parent's perspective. J Paediatr Child Health 2011, 47:557-562.

23. Bray P, Bundy AC, Ryan MM, North KN, Everett A: Health-related quality of life in boys with Duchenne muscular dystrophy: agreement between parents and their sons. J Child Neurol 2010, 25:1188-1194.

24. Chen JY: Mediators affecting family function in families of children with Duchenne muscular dystrophy. Gaoxiong Yi Xue Ke Xue Za Zhi 2008, 24:514-522.

25. Chen JY, Chen SS, Jong YJ, Yang YH, Chang YY: A comparison of the stress and coping strategies between the parents of children with Duchenne muscular dystrophy and children with a fever. J Pediatr Nurs 2002, 17:369-379.

26. Chen JY, Clark MJ: Family function in families of children with Duchenne muscular dystrophy. Fam Community Health 2007, 30:296-304.

27. Chen J-Y, Clark M-J: Family resources and parental health in families of children with Duchenne muscular dystrophy. J Nurs Res 2010, 18:239-248.

28. Cyrulnik SE, Fee RJ, Batchelder A, Kiefel J, Goldstein E, Hinton VJ: Cognitive and adaptive deficits in young children with Duchenne muscular dystrophy (DMD). J Int Neuropsychol Soc 2008, 14:853-861.

29. Fee RJ, Hinton VJ: Resilience in children diagnosed with a chronic neuromuscular disorder. J Dev Behav Pediatr 2011, 32:644-650.

30. Firth M, Gardnermedwin D, Hosking G, Wilkinson E: Interviews with parents of boys suffering from Duchenne muscular-dystrophy. Dev Med Child Neurol 1983, 25:466-471.

31. Garralda ME, McConachie H, Le Couteur A, Sriranjan S, Chakrabarti I, Cirak S, Guglieri M, Bushby K, Muntoni F: Emotional impact of genetic trials in progressive paediatric disorders: a dose-ranging exon-skipping trial in Duchenne muscular dystrophy. Child Care Health Dev 2013, 39:449-455.

32. Garralda ME, Muntoni F, Cunniff A, Caneja AD: Knee-ankle-foot orthosis in children with duchenne muscular dystrophy: user views and adjustment. Eur J Paediatr Neurol 2006, 10:186-191.

33. Hanayama K, Liu M, Higuchi Y, Fujiwara T, Tsuji T, Hase K, Ishihara T: Dysphagia in patients with Duchenne muscular dystrophy evaluated with a questionnaire and videofluorography. Disabil Rehabil 2008, 30:517-522.

34. Hendriksen JG, Poysky JT, Schrans DG, Schouten EG, Aldenkamp AP, Vles JS: Psychosocial adjustment in males with Duchenne muscular dystrophy: psychometric properties and clinical utility of a parent-report questionnaire. J Pediatr Psychol 2009, 34:69-78.

35. James CA, Hadley DW, Holtzman NA, Winkelstein JA: How does the mode of inheritance of a genetic condition influence families? A study of guilt, blame, stigma, and understanding of inheritance and reproductive risks in families with X-linked and autosomal recessive diseases. Genet Med 2006, 8:234-242
36. Jarvinen $\mathrm{O}$, Lehesjoki $\mathrm{AE}$, Lindlof $\mathrm{M}$, Uutela A, Kaariainen $\mathrm{H}$ : Carrier testing of children for two X-linked diseases: a retrospective study of comprehension of the test results and social and psychological significance of the testing. Pediatrics 2000, 106:1460-1465.

37. Jutai J, Rigby P, Ryan S, Stickel S: Psychosocial impact of electronic aids to daily living. Assist Technol 2000, 12:123-131.

38. Kemper AR, Wake MA: Duchenne muscular dystrophy: issues in expanding newborn screening. Curr Opin Pediatr 2007, 19:700-704

39. Kenneson A, Bobo JK: The effect of caregiving on women in families with Duchenne/Becker muscular dystrophy. Health Soc Care Community 2010, 18:520-528.

40. Kinali M, Manzur AY, Mercuri E, Gibson BE, Hartley L, Simonds AK, Muntoni F: UK physicians' attitudes and practices in long-term non-invasive ventilation of Duchenne Muscular Dystrophy. Pediatr Rehabil 2006, 9:351-364.

41. Kohler M, Clarenbach CF, Boeni L, Brack T, Russi EW, Bloch KE: Quality of life, physical disability, and respiratory impairment in Duchenne muscular dystrophy. Am J Respir Crit Care Med 2005, 172:1032-1036.

42. Manzur AY, Kinali M, Muntoni F: Update on the management of Duchenne muscular dystrophy. Arch Dis Child 2008, 93:986-990.

43. Marini A, Lorusso ML, D'Angelo MG, Civati F, Turconi AC, Fabbro F, Bresolin $\mathrm{N}$ : Evaluation of narrative abilities in patients suffering from Duchenne Muscular Dystrophy. Brain Lang 2007, 102:1-12.

44. Pangalila RF, van den Bos GA, Stam HJ, van Exel NJ, Brouwer WB, Roebroeck ME: Subjective caregiver burden of parents of adults with Duchenne muscular dystrophy. Disabil Rehabil 2012, 34:988-996.

45. Parker AE, Robb SA, Chambers J, Davidson AC, Evans K, O'Dowd J, Williams AJ, Howard RS: Analysis of an adult Duchenne muscular dystrophy population. QJM 2005, 98:729-736.

46. Parsons EP, Clarke AJ, Hood K, Lycett E, Bradley DM: Newborn screening for Duchenne muscular dystrophy: a psychosocial study. Arch Dis Child Fetal Neonatal Ed 2002, 86:F91-F95.

47. Pehler SR, Craft-Rosenberg M: Longing: the lived experience of spirituality in adolescents with Duchenne muscular dystrophy. J Pediatr Nurs 2009, 24:481-494.

48. Read J, Kinali M, Muntoni F, Garralda ME: Psychosocial adjustment in siblings of young people with Duchenne muscular dystrophy. Eur $J$ Paediatr Neurol 2010, 14:340-348.

49. Read J, Kinali M, Muntoni F, Weaver T, Garralda ME: Siblings of young people with Duchenne muscular dystrophy - A qualitative study of impact and coping. Eur J Paediatr Neurol 2011, 15:21-28.

50. Simon VA, Resende MB, Simon MA, Zanoteli E, Reed UC: Duchenne muscular dystrophy: quality of life among 95 patients evaluated using the Life Satisfaction Index for Adolescents. Arq Neuropsiquiatr 2011, 69:19-22.

51. Steele M, Taylor E, Young C, McGrath P, Lyttle BD, Davidson B: Mental health of children and adolescents with Duchenne muscular dystrophy. Dev Med Child Neurol 2008, 50:638-639.

52. Uzark K, King E, Cripe L, Spicer R, Sage J, Kinnett K, Wong B, Pratt J, Varni JW: Health-related quality of life in children and adolescents with Duchenne muscular dystrophy. Pediatrics 2012, 130:E1559-E1566.

53. van Wijk E, Messelink BJ, Heijnen L, de Groot IJ: Prevalence and psychosocial impact of lower urinary tract symptoms in patients with Duchenne muscular dystrophy. Neuromuscul Disord 2009, 19:754-758.

54. Vandervelde L, Van den Bergh PY, Goemans N, Thonnard JL: Activity limitations in patients with neuromuscular disorders: a responsiveness study of the ACTIVLIM questionnaire. Neuromuscul Disord 2009, 19:99-103.

55. Balkefors $V$, Mattsson E, Pernow $Y$, Saaf M: Functioning and quality of life in adults with mild-to-moderate osteogenesis imperfecta. Physiother Res Int 2012.

56. Bernehall Claesson I, Brodin J: What families with children with brittle bones want to tell. Child Care Health Dev 2002, 28:309-315.

57. Brodin J: Children and adolescents with brittle bones - psychosocial-aspects. Child Care Health Dev 1993, 19:341-347.

58. Cole DE: Psychosocial aspects of osteogenesis imperfecta: an update. Am J Med Genet 1993, 45:207-211.

59. Daly K Wisbeach A, Sanpera I Jr, Fixsen JA: The prognosis for walking in osteogenesis imperfecta. J Bone Joint Surg Br 1996, 78:477-480.

60. Engelbert RH, Uiterwaal CS, Gulmans VA, Pruiis H, Helders PJ: Osteogenesis imperfecta in childhood: prognosis for walking. J Pediatr 2000, 137:397-402.

61. Kok DJ, Uiterwaal C, van Dongen AJ, Kramer PPG, Pruijs HEH, Engelbert RHH, Verbout AJ, Schweitzer DH, Sakkers RJB: The interaction between 
Sillence type and BMD in osteogenesis imperfecta. Calcif Tissue Int 2003, 73:441-445.

62. Montpetit K, Dahan-Oliel N, Ruck-Gibis J, Fassier F, Rauch F, Glorieux F: Activities and participation in young adults with osteogenesis imperfecta. J Pediatr Rehabil Med 2011, 4:13-22.

63. Seikaly MG, Kopanati S, Salhab N, Waber P, Patterson D, Browne R, Herring JA: Impact of alendronate on quality of life in children with osteogenesis imperfecta. J Pediatr Orthop 2005, 25:786-791.

64. Suskauer SJ, Cintas HL, Marini JC, Gerber LH: Temperament and physical performance in children with Osteogenesis Imperfecta. Pediatrics 2003, 111:e153-e161.

65. Szczepaniak-Kubat A, Kurnatowska O, Jakubowska-Pietkiewicz E, Chlebna-Sokol D: Assessment of quality of life of parents of children with Osteogenesis Imperfecta. Adv Clin Exp Med 2012, 21:99-104.

66. Tolboom N, Cats EA, Helders PJ, Pruijs JE, Engelbert RH: Osteogenesis imperfecta in childhood: effects of spondylodesis on functional ability, ambulation and perceived competence. Eur Spine J 2004, 13:108-113.

67. Van Brussel M, Takken T, Uiterwaal C, Pruijs HJ, Van der Net J, Helders PJM, Engelbert RHH: Physical training in children with osteogenesis imperfecta. J Pediatr 2008, 152:111-116.

68. Widmann R, Laplaza J, Bitan F, Brooks C, Root L: Quality of life in osteogenesis imperfecta. Int Orthop 2002, 26:3-6.

69. Widmann RF, Bitan FD, Laplaza J, Burke SW, DiMaio MF, Schneider R: Spinal deformity, pulmonary compromise, and quality of life in osteogenesis imperfecta. Spine 1999, 24:1673-1678.

70. Curran AL, Sharples PM, White C, Knapp M: Time costs of caring for children with severe disabilities compared with caring for children without disabilities. Dev Med Child Neurol 2001, 43:529-533.

71. van den Tweel XW, Hatzmann J, Ensink E, van der Lee JH, Peters M, Fijnvandraat K, Grootenhuis M: Quality of life of female caregivers of children with sickle cell disease: a survey. Haematologica 2008, 93:588-593.

72. Zurynski Y, Frith K, Leonard H, Elliott E: Rare childhood diseases: how should we respond? Arch Dis Child 2008, 93:1071-1074.

73. Dogba MJ, Bedos C, Durigova M, Montpetit K, Wong T, Glorieux F, Rauch F The Impact of Severe Osteogenesis Imperfecta on the Lives of Young Patients and Their Parents - a Qualitative Analysis. BMC Pediatr 2013, 13:153.

74. Ratliffe CE, Harrigan RC, Haley J, Tse A, Olson T: Stress in families with medically fragile children. Issues Compr Pediatr Nurs 2002, 25:167-188.

75. Kazak AE, Reber M, Snitzer L: Childhood chronic disease and family functionning- a study of phenylketonuria. Pediatrics 1988, 81:224-230.

76. Battista RN, Blancquaert I, Laberge AM, van Schendel N, Leduc N: Genetics in health care: an overview of current and emerging models. Public Health Genomics 2012, 15:34-45.

77. Zurynski Y, Peadon E, Bower C, Elliott EJ: Impacts of national surveillance for uncommon conditions in childhood. J Paediatr Child Health 2007, 43:724.

78. Burton H, Sanderson S, Shortland G, Lee P: Needs assessment and review of services for people with inherited metabolic disease in the United Kingdom. J Inherit Metab Dis 2006, 29:667-676.

79. Eiser C, Morse R: A review of measures of quality of life for children with chronic illness. Arch Dis Child 2001, 84:205-211.

80. Rajmil L, Perestelo-Perez L, Herdman M: Quality of life and rare diseases. Adv Exp Med Biol 2010, 686:251-272.

81. Paterson CR, Rosalind MH: Life expectancy in osteogenesis imperfecta. Br Med J 1996, 312:351.

\section{Submit your next manuscript to BioMed Central and take full advantage of:}

- Convenient online submission

- Thorough peer review

- No space constraints or color figure charges

- Immediate publication on acceptance

- Inclusion in PubMed, CAS, Scopus and Google Scholar

- Research which is freely available for redistribution

Submit your manuscript at www.biomedcentral.com/submit 